Karpenko Maryna, $\mathrm{PhD}$ in Economics

Kyiv National University of Trade and Economics, Kyiv, Ukraine

ORCID 0000-0003-4393-7429

\title{
DAIRY BUSINESS IN CONDITIONS OF GEOPOLITICAL AND GEO-ECONOMIC CHANGES
}

The dairy business of Ukraine experiences the complex development stage associated with the changes of geopolitical and geo-economic conditions that influence both the foreign economic activities of the enterprises and the situation in the domestic market. The article researches the current state of the milk and dairy products market of Ukraine, analyzes the dynamics of the purchasing prices for milk and analyzes the changes in the Ukrainian dairy products export structure. It also emphasizes the branch problems and proposes the directions of their solving.

Keywords: dairybusiness, milkquality, export, import, international competitiveness.

Карпенко Марина. Молочний бізнес в умовах геополітичних та геоекономічних змін

Молочний бізнес Украӥни проходить непросту стадію розвитку, пов'язану зі змінам игеополітичних та геоекономічних умов, що впливають як на зовнішньоекономічну діяльність підприємств такі на ситуачію на внутрішньому ринку. У статті досліджено поточний стан ринку молока та молочної продукції України, проаналізовано динаміку закупівельних цін на молоко, проаналізовано зміни у структурі експорту молочної продукції України. Виділено проблемні питання галузі та запропоновано напрямки їх вирішення.

Ключові слова: молочний бізнес, молочна якість, експорт, імпорт, міжнародна конкурентоспроможність.

Relevance of research topic. The development of dairy branch should be one of the priorities to stabilize the Ukrainian agricultural economy. The increased competition in the dairy market in accordance with the Association Agreement signing between Ukraine and the European Union, the customers' requirements to the products quality along with the decrease of the purchasing power of the population contribute to the necessity of analysis and search for the branch problems solutions. 
Formulation of the problem. Despite the large number of researches concerning the dairy industry, the problems of improving competitiveness of the Ukrainian dairy business both in domestic and external markets remain unsolved.

Analysis of recent researches and publications. The problems of the dairy market development and dairy products competitive growth are covered by the works by V.M. Bondarenko, T.L. Keranchuk, N.V. Ovsienko, M.I. Vasylchak, V.O. Rybintsev, S.O. Stepanchuk, T.M. Mostenska, V. Marchenko, V.V. Dzhedzhula., I. Yu. Yepifanova and others.

Presenting main material. About 260 plants, which possess the industrial capacities for raw milk processing and dairy products manufacturing, function in Ukraine. All the enterprises are private. There are the enterprises united in private dairy holdings, while the others are in the market independently.

The raw milk producers are represented in Ukraine by two categories of farming units:

1. agricultural enterprises - legal entities;

2. individual sector - physical persons (population).

These days the Ukrainian milk and dairy products manufacturers face the number of problems that obstruct their businesses development. The stock number of cows constantly declines in all categories of economic entities. Since the start of the year, the dairy herd decreased by 92 thousand cows and count 1.906 million cows. Including, the agricultural enterprises count 448.5 thousand cows, which is $5.4 \%$, or 25.7 thousand less than last year. The individual sector keeps 1.458 million cows, which is $4.4 \%$, or 66 thousand cows less than during the similar period last year.

For 8 months of 2019, the total volumes of the milk total output in Ukraine decreased by $3.5 \%$, or 243 thousand tons as compared to the similar period last year to count 6.74 million tons. The milk production volumes decreased in all categories of farming units: in agricultural enterprises by $1.3 \%$ to count 1.88 million tons, in individual sector by $4.3 \%$ to count 4.861 million tons.

The market receives milk in less large volumes than due, which caused the price excitement in the raw products market and its strict monopolization.

Currently the price level runs to $9.5-10.86 \mathrm{UAH} / \mathrm{kg}$, at the base values of fat $3.4 \%$ and protein $-3.0 \%$. By contrast, in August the milk average cost in the EU was 0.34 EUR per $\mathrm{kg}$, that in terms of the base values established in Ukraine is 8.21 $\mathrm{UAH} / \mathrm{kg}$ at the rate of $1 €=27.86 \mathrm{UAH}$. For 28 members of the EU, three countries (Malta, Cyprus, and Italy) have the higher milk prices than those of the Ukrainian producers, in equal comparative conditions.

During last few years, several changes in the foreign economic activities of dairy business enterprises of Ukraine happened. Earlier the main buyer of dairy products was the Russian Federation, towhere hard cheeses were exported. After the embargo of deliveries to the Russian Federation, the geography of export deliveries extended. The Figure 1 represents the main importers of the Ukrainian dairy products.

The assortment of the exported products also changed. The cheese export decreased significantly, instead of this the deliveries of the other dairy products 
increased - drinking milk, whey, fermented milk products, powdered milk, and butter. The Figure 2 represents the dairy products assortment that is exported. As of today, 22 milk processing plants of Ukraine are inspected by the EU against the correspondence to the European requirements and are included to the official register of the EU exporters. They have the right to export the products to the EU countriesmembers.

The current price environment in the dairy raw products market emerged to be such that the milk processing plants are not ready to pay the price offered by the dairy raw products sellers.

Non-condensed milk and cream

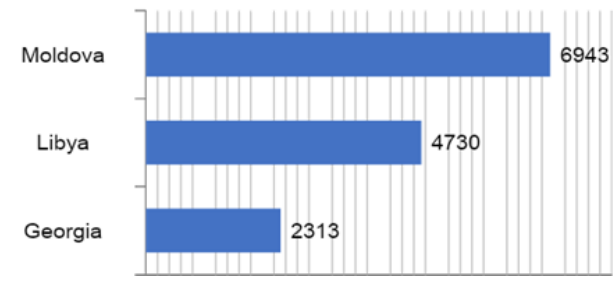

Fermented milk products
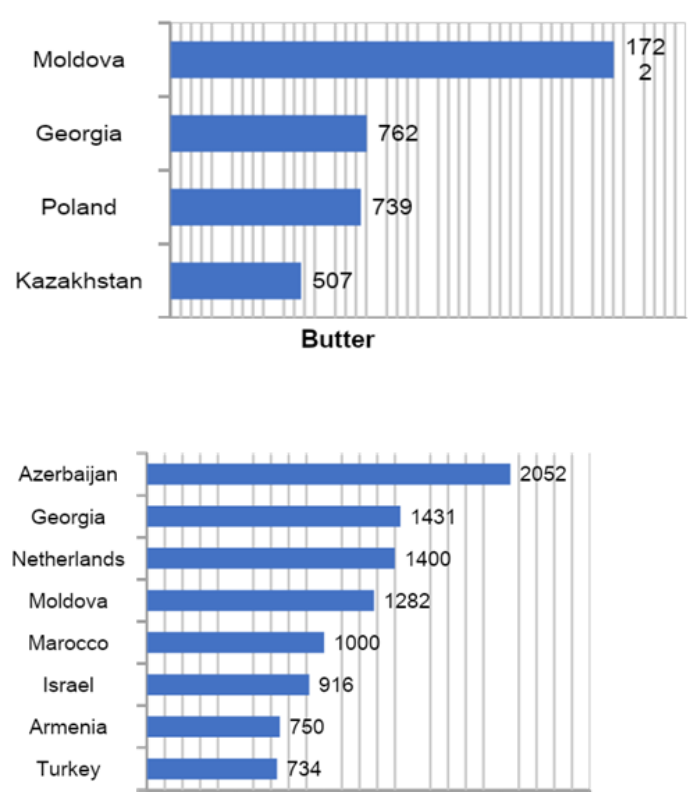

Ice-cream

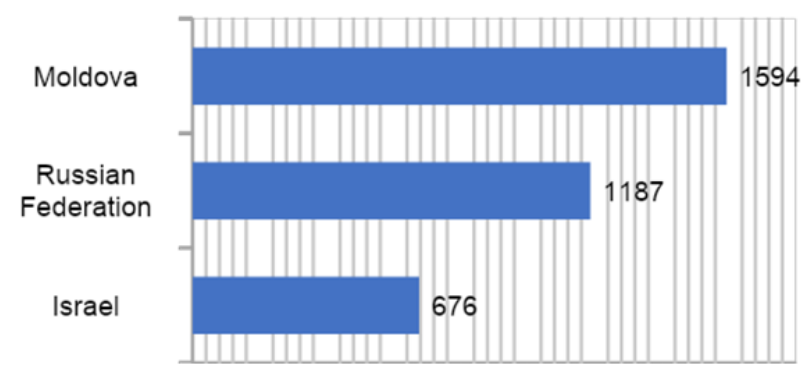

Condensed milk
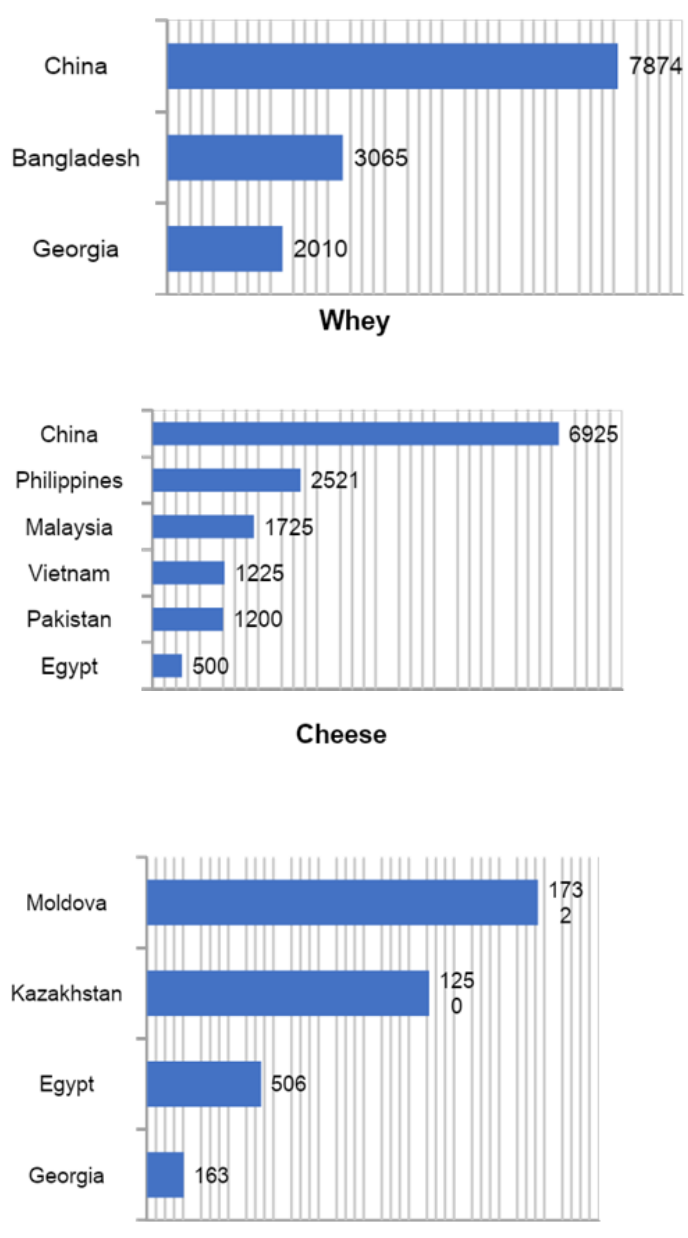

Casein

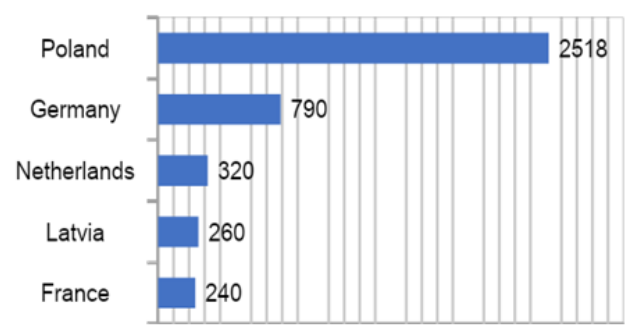

Figure 1. The main importers of Ukrainian dairy products, tons (customs statistics) 
The sale of dairy products in the domestic market fell to the lowest level. The increasing prices for milk and the high tariffs for the electrical energy and combustible and lubrication materials as well as the other expenses form the high prime cost of the final dairy products. The purchasing capacity of the ordinary Ukrainians, like in previous years, remains low because of the low income of the citizens. The physiological consumption norm is $340 \mathrm{~kg}$ per person. The actual consumption is $197 \mathrm{~kg} /$ person, which is $41 \%$ less than the determined physiological norm for a person.

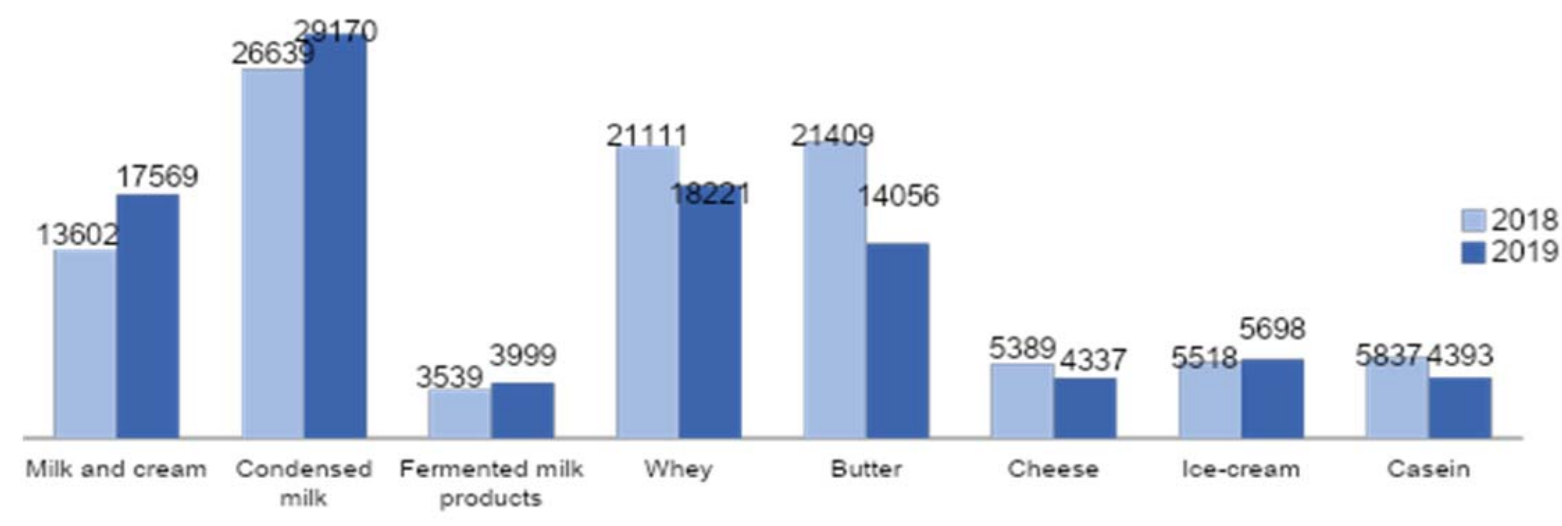

Figure 2. The Ukrainian dairy products export structure, tons (2018 - 8 months of 2019, customs statistics)

Owing to the determined factors the dairy products import from Poland, France, Italy and Baltic countries displaces the national products in our domestic market as far as they are cheaper than the national ones. The national producers gradually lose the Ukrainian customers. The Ukrainian dairy products are uncompetitive in the external market because of their high prime cost.

According to the Association Agreement signed between Ukraine and the European Union, the unilateral trade preferences were introduced for the transition period by way of determining the import duties rate and tariff quotas volumes.

Under the current prices for dairy products of Ukraine is incapable to take up even the determined import quotas of the EU. As of September, the quota for butter is used by half (48\%), for the products of processed milk - by 33.3\% (Table 1).

Table 1

\section{The state of using the tariff quotas for Ukrainian dairy products export to the European Union in 2019 (as of September)}

\begin{tabular}{|l|c|c|c|}
\hline \multicolumn{1}{|c|}{ Product name } & $\begin{array}{c}\text { Determined, } \\
\text { tons }\end{array}$ & $\begin{array}{c}\text { Used, } \\
\text { tons }\end{array}$ & $\begin{array}{c}\text { Remaining part till the end } \\
\text { of the year, tons }\end{array}$ \\
\hline Butter & 2500,00 & 1199,00 & 1301,00 \\
\hline Powdered milk & 3600,00 & 500,00 & 3100,00 \\
\hline $\begin{array}{l}\text { Other dairy products (milk, yoghurts, } \\
\text { condensed products and others) }\end{array}$ & 9200,00 & 1100,00 & 8100,00 \\
\hline
\end{tabular}


In August this year as compared to August last year the export of the Ukrainian dairy products decreased by all the products positions. Instead of that, the import in cost equivalent increased by $64 \%$. Particularly, the cheeses deliveries increased. Since the beginning of the year, Ukraine imported cheeses in natural weight by 3.2 times more than exported. In the near future, we do not expect any fundamental changes in external trade of both cheeses and cheese products. The cheeses import will continue to grow. The considerable competition in the external market, fall in the exchange rate resulted in the fact that the Ukrainian products export almost stopped.

The floating assets of the Ukrainian milk processing plants are limited, the enterprises are obliged to take on loans to purchase the raw products. The trade supermarkets continue to dictate their own conditions: the due period for the products is 60 days and more. The domestic market sank maximally, the consumption decreased by more than $30 \%$ as compared to the last year.

Conclusion. Taking into consideration the above, we may conclude that the dairy business enterprises of Ukraine are in bad streak. The urgent measures to improve their competitiveness both in external and domestic markets are needed. The taxpayer support to develop the farming units and build farms, to create the production cooperatives, family farms, to develop forage base, to acquire milking installations, heat exchangers is required. There exist the state programs of the livestock farming development and servicing cooperatives creation, but the funds are not sufficient. The measures to improve the milk raw products quality and to determine the competitive price for raw products are required. It is required to exclude from the total income of small farmers $100 \%$ of funds received from the sales of milk used for processing, in case of the subsidies provision for residential and utilities services organizations, as well as to give the possibility to take on preferential loans and/or partial compensation of the local waste treatment plants construction cost.

In order to improve the dairy products competitiveness in external markets it is important to bring the base norms of the fat and protein mass percentage in cow raw milk to the European norms.

In order to improve competitiveness in the domestic market it is required to optimize the logistic, marketing expenses while selling the products, to introduce the VAT privileged rate for the final dairy products sold in the domestic market. The measures to weaken the increasing expansion of imported dairy products to the domestic market are required as well.

\section{REFERENCES}

1. Dzhedzhula V. V., Yepifanova I. Ju., Dzjubko M. Ju.(2018) Naprjamy pidvyshhennja efektyvnosti dijaljnosti pidpryjemstv molochnoji ghaluzi [Areas of 
increasing the efficiency of the dairy industry]. Investyciji: praktyka ta dosvid, \#. 11, pp. 12-14.

2. Tyvonchuk S. V., Tyvonchuk Ja. O., Pavlocjka T. P. (2017) Rozvytok rynku vyrobnyctva moloka $\mathrm{v}$ Ukrajini $\mathrm{v}$ konteksti jevrointeghracijnykh procesiv [Development of milk production market in Ukraine in the context of European integration processes]. Ekonomika APK, no 4, pp. 25-31.

3. About milk and dairy products: Law of Ukraine dated 04/05/15 \# 1870-IV [electronic resource]. - access mode: htpp//zakon.rada.gov.ua/laws/show/1870-15

4. Keranchuk T. L. (2017) Molochna ghaluzj Ukrajiny: perspektyvy i problemy rozvytku [Ukraine's Dairy Industry: Prospects and Problems of Development]. Skhidna Jevropa: Ekonomika, biznes ta upravlinnja (electronic journal), \# 3 (08), pp. 133-136. Available at: http://www.easterneurope-ebm.in.ua/journal/ 8_2017/25.pdf 